\title{
GELLING POLYSACCHARIDE AS THE ELECTROLYTE MATRIX IN A DYE-SENSITIZED SOLAR CELL
}

\author{
ŽELIRNI POLISAHARID KOT ELEKTROLITNA OSNOVA V \\ SOLARNIH CELICAH, OBČUTLJIVIH NA BARVILA
}

\author{
Jose Paolo Bantang1, Drexel Camacho ${ }^{1,2}$ \\ ${ }^{1}$ De La Salle University, Chemistry Department, 2401 Taft Avenue, 1004 Manila, Philippines \\ ${ }^{2}$ De La Salle University, Organic Materials and Interfaces Unit, CENSER, 2401 Taft Avenue, 1004 Manila, Philippines \\ drexel.camacho@dlsu.edu.ph \\ Prejem rokopisa - received: 2016-09-30; sprejem za objavo - accepted for publication: 2017-03-16
}

doi:10.17222/mit.2016.294

\begin{abstract}
Hydrophilic polysaccharide, $\kappa$-carrageenan, was utilized as the polymer matrix in gel-electrolyte systems for dye-sensitized solar-cell (DSSC) applications. The influence of the solvent system was investigated to optimize the solubility of $\kappa$-carrageenan and tetrabutylammonium-iodide (TBAI)/I $\mathrm{I}_{2}$ electrolytes by minimizing the water content because of its unfavorable effect on DSSCs. We report herein that two solvent systems, a water/acetonitrile mixed solvent and DMSO, were found to effectively dissolve the components. The composite natures of the $\kappa$-carrageenan-electrolyte systems in these solvents were confirmed with an FTIR analysis. The presence of $\kappa$-carrageenan did not impede the electrochemical properties of the electrolytes, as confirmed with cyclic voltammetry, electrochemical impedance spectroscopy and linear sweep voltammetry. The incorporation of the gel electrolytes in DSSCs showed that the DMSO system exhibited better solar-cell efficiency compared to the mixed-solvent system.

Keywords: dye-sensitized solar cell, $\kappa$-carrageenan, gel electrolyte, electrochemical impedance spectroscopy, ionic conductivity
\end{abstract}

Hidrofilni polisaharid, $\kappa$-karagen, je bil uporabljen kot polimerna osnova v želirno elektrolitskih sistemih za uporabo v barvno občutljivih sončnih celicah (angl. DSSC). Da bi izboljšali topnost $\kappa$-karagena in elektrolitov tetrabutilamonijevega iodida (TBAI)/I2 z zmanjšanjem vsebnosti vode, zaradi njenega neželenega učinka na DSSC, je bila preiskovana občutljivost sistema topil. Clanek poroča, da sta bila najdena dva nova sistema topil, mešanica topila voda/acetonitril in DMSO, ki učinkovito raztopita komponente. Lastnosti oz. obnašanje kompozitov elektrolitskega sistema $\kappa$-karagen v teh raztopinah, so bile potrjene z FTIR-analizo. Prisotnost $\kappa$-karagenskega elektrolitnega sistem ni predstavljala ovire za imepdančno spektroskopijo in lienarno "sweep" voltametrijo. Vključitev gel-elektrolitov v DSSC je pokazala, da DMSO-sistem kaže boljšo solarno celično učinkovitost kot sistem mešanih topil.

Ključne besede: barvno občutljive sončne celice, rastlinska želatina $\kappa$-karagen, gel-elektrolit, elektrokemična impedančna spekroskopija, ionska prevodnost

\section{INTRODUCTION}

Gel-polymer electrolytes are promising materials for a potential incorporation in electrochemical devices ${ }^{1}$ such as dye-sensitized solar cells (DSC). This is because their mechanical behavior is that of solids, yet their internal structure is flexible and their conductivity behavior resembles that of a liquid state allowing a good electrode/electrolyte contact. ${ }^{2,3}$ Moreover, its ease of fabrication allows more tunability in designing systems for specific applications.

Natural polysaccharide is a potential matrix for polymer electrolytes owing to its hydrophilic and gel-forming capacity that traps the solvent together with the redox couple inside the polymer matrix. The high water-retention property of polysaccharide-based polymer-electrolyte systems was shown to promote good ionic conductivities and thermal stability. ${ }^{4,5}$ Agarose, ${ }^{6,7}$ cellulose and its derivatives ${ }^{8,9}$ and $\kappa$-carrageenan ${ }^{10}$ are the gel-forming natural polysaccharides that have been used as polymer-electrolyte (PE) systems for dye-sensitized-solar-cell (DSSC) applications. To maximize the water-retention property of these polysaccharide-based gel systems, an aqueous medium is necessary. However, we can see that water disturbs the interfacial attachment of dyes to $\mathrm{TiO}_{2}$. Thus, it is highly desirable to develop a polysaccharide-based electrolyte system in a smaller amount of water or in a non-aqueous medium.

$\kappa$-Carrageenan, which is composed mainly of disaccharide units of $\beta$-D-galactopyranose with either an $\alpha$-D-galactopyranose or 3,6-anhydrogalactose is a promising polysaccharide matrix for electrolytes due to its hydrophilic, linear and sulfated properties. The electrostatic interactions of ions with hydroxyl groups and sulfate groups in the main chain are essential to the conduction mechanism of a polysaccharide electrolyte system. ${ }^{11,12}$ The promising features of $\kappa$-carrageenan as a polymer-electrolyte system can be potentially applied to DSSCs. Solid-state DSSCs using carrageenan-gel electrolyte systems were fabricated by soaking the aqueous polymer gel with the redox electrolytes ${ }^{11}$ and forming thin polymer membranes ${ }^{13}$ leading to decent efficiencies. To date, studies on the preparation and characterization of carrageenan-electrolyte systems have been limited 
only to pure aqueous systems. A significant amount of water present in the electrolyte systems applied to DSSCs causes a decrease in the photocurrent of the device associated with dye desorption, iodate formation and a decrease in the electron lifetime. ${ }^{14}$ Hence, the amount of water must be controlled, if not eliminated. It is the objective of this paper to investigate the influence of the solvent system on carrageenan electrolyte and its performance in a DSSC. This paper reports, for the first time, on a novel carrageenan-based electrolyte system with an iodide/tri-iodide redox couple prepared using a mixed solvent system and a non-aqueous solvent.

\section{MATERIALS AND METHODS}

\subsection{Optimization of the $\kappa$-carrageenan electrolyte sys- tem}

Different $\kappa$-carrageenan (Shemberg, Philippines) biopolymer gel electrolytes were optimized by varying the ratio of water/acetonitrile and the amount of polymer with a constant amount of tetrabutylammonium iodide (TBAI, Sigma Aldrich, a reagent grade of $98 \% ; 20 \%$ $w / w$ of TBAI with respect to $\kappa$-carrageenan) and iodine ( $\mathrm{I}_{2}$, Aldrich, $=99.99 \%$ metal basis $)$. The molar ratio of $\mathrm{TBAI} / \mathrm{I}_{2}$ was $4: 1$. The ratio of water/ACN was optimized by dissolving $\kappa$-carrageenan $(0.2 \mathrm{~g})$ with $\mathrm{TBAI} / \mathrm{I}_{2}$ in different solvent systems consisting of $100 \%$ water, 3:1 water/ACN, 1:1 water/ACN, 1:3 water/ACN, and $100 \%$ $\mathrm{ACN}$ at $80{ }^{\circ} \mathrm{C}$ until a homogeneous solution was formed. Thin films were formed by casting solutions on plastic petri dishes and slowly drying in air. Different biopolymer electrolytes were prepared using the same procedure by varying the concentration of $\kappa$-carrageenan $(0,0.5$, $1.0,1.5$ and $2 \% \mathrm{w} / \mathrm{v})$. Using the optimized parameters, $\kappa$-carrageenan gel electrolytes containing $20 \% \mathrm{w} / \mathrm{w}$ (with respect to the amount of $\kappa$-carrageenan) of other salts such as potassium iodide (Sigma Aldrich) and trimethylsulfonium iodide (TMSI, Sigma Aldrich) were also prepared.

A liquid-state polymer electrolyte and a gel-state polymer electrolyte based on $\kappa$-carrageenan were prepared by dissolving $1 \% \mathrm{w} / \mathrm{v}$ or $2 \% \mathrm{w} / \mathrm{v}$ of the polysaccharide in $2 \mathrm{~mL}$ of dimethylsulfoxide at $70{ }^{\circ} \mathrm{C}$. Tetrabutylammonium iodide $(0.5 \mathrm{M}), \mathrm{I}_{2}(0.05 \mathrm{M})$ and LiI $(0.1 \mathrm{M})$ were added to the $\kappa$-carrageenan solution. As the control, the same composition was used without adding the biopolymer.

\subsection{Fabrication of dye-sensitized solar cells (DSSCs)}

The photoanode was prepared spreading a $\mathrm{TiO}_{2}$ paste (Solaronix, Ti-Nanoxide T/SP) on a fluorine-doped tin-oxide (FTO) conducting glass (TCO22-7) with the doctor-blading method. The active area of the photoanode was fixed to $1 \mathrm{~cm} \times 1 \mathrm{~cm}$ with adhesive tapes. The deposited paste was sintered at $450{ }^{\circ} \mathrm{C}$ for $30 \mathrm{~min}$ and cooled down slowly to room temperature. The deposited
$\mathrm{TiO}_{2}$ film was soaked in a dye solution containing a ruthenium dye (Ruthenizer 535-bisTBA, Solaronix) in ethanol for $24 \mathrm{~h}$. The counter electrode was prepared by sintering an FTO conducting glass coated with a platinum solution (Platisol 41121, Solaronix) at $450{ }^{\circ} \mathrm{C}$ for 30 mins. The photoanode and counter electrode were sealed with a hot-melt thermoplastic material called Surlyn (DuPont, thickness of $60 \mu \mathrm{m}$ ), also acting as a spacer. A dye-sensitized solar cell was fabricated by inserting a hot gel-electrolyte solution in a pre-drilled hole on the counter electrode. Three different solar cells were fabricated containing different iodide salts (KI, TMSI, and TBAI) in a water/ACN $\kappa$-carrageenan matrix. A control DSSC was prepared using an acetonitrilebased liquid electrolyte (Iodolyte AN50, Solaronix). The same process was used for the fabrication of a DSSC incorporating gel electrolytes in DMSO.

\subsection{Characterization}

The surface morphology and thickness of the thin films were characterized using scanning electron microscopy (JEOL JSM-5310). The electrical conductivity was measured using the 4-point probe Van der Pauw method. In brief, four wires were attached to the corners of a $1 \mathrm{~cm} \times 1 \mathrm{~cm}$ thin film using a silver paste. The voltage at a constant current was measured. The resistivity and electrical conductivity were calculated using the following equations:

Resistivity, $s=\frac{\pi d}{\ln 2}\left(\frac{V_{1}}{l_{2}}+\frac{V_{2}}{l_{2}}\right) f\left(\frac{R_{1}}{R_{2}}\right)$ and Electrical conductivity, $\rho=1 / \mathrm{s}$, where $d, V, I$ and $f\left(R_{1} / R_{2}\right)$ refer to the thickness, potential, current and van der Pauw function, respectively.

The redox properties of the $\kappa$-carrageenan gel electrolyte were characterized using 3-electrode cyclic voltammetry (Powerlab/4SP potentiostat). The electrodes composed of the $\mathrm{Ag} / \mathrm{AgCl}$ reference electrode, platinum-wire counter electrode and glassy-carbon working electrode were pierced through the gel. Electrochemical impedance spectroscopy (Metrohm Autolab potentiostat PGSTAT128N) was obtained by sandwiching the gel electrolyte in between two platinum-coated FTO conducting-glass electrodes. The active area was fixed to $1 \times 1 \mathrm{~cm}^{2}$ and the thickness of the spacer was about $50 \mu \mathrm{m}$. The frequency was set from $10^{6} \mathrm{~Hz}$ to $10^{-1} \mathrm{~Hz}$ with an AC applied voltage of $10 \mathrm{mV}$. The ionic conductivity $(\sigma)$ of the gel electrolyte was calculated from the solution resistance $\left(R_{\mathrm{s}}\right)$ using Equation (3):

$$
\sigma=\frac{L}{A R_{\mathrm{s}}}
$$

The solution resistance $\left(R_{\mathrm{s}}\right)$ is determined as the intercept of the Nyquist plot against the real part of the impedance or the horizontal axis. The variables $L$ and $A$ correspond to the thickness of the spacer and the active area, respectively. The solar-cell parameters such as the 
open-circuit voltage, short-circuit current, fill factor and efficiency of the fabricated dye-sensitized solar cells with $\kappa$-carrageenan gel electrolyte were assessed using a $100 \mathrm{~mW} / \mathrm{cm}^{2}$ AM 1.5 solar simulator (Abet Technologies) coupled with a potentiostat to obtain a currentvoltage (IV) curve.

\section{RESULTS AND DISCUSSIONS}

\subsection{Carrageenan-electrolyte system in a mixed solvent system}

Acetonitrile $(\mathrm{ACN})$, which is a common organic solvent used for preparing liquid electrolytes for DSSC applications, does not dissolve $\kappa$-carrageenan. Thus, to form $\kappa$-carrageenan electrolytes containing a redox couple $\mathrm{I}^{-} / \mathrm{I}_{3}{ }^{-}$(from TBAI and $\mathrm{I}_{2}$ ), the amount of water is crucial to dissolve the hydrophilic polysaccharide. ${ }^{15}$ Using water only as the solvent, a black film was formed with observable colorless crystals (Figure 1a) indicating the unsuccessful dissolution of both TBAI salt and iodine. Likewise, crystallization of the salt was formed on the surface of the film prepared using a 3:1 $v / v$ water/ACN system (Figure 1b). The salt crystallization is attributed to the relative insolubility of the salt in a water-rich solvent. Moreover, the presence of the salt and iodine crystals on the film surface indicates that it fails to dissociate in the polymer matrix, leading to an unsuccessful incorporation of the charge-carrier redox couple $\mathrm{I}^{-} / \mathrm{I}_{3}{ }^{-}$. For a $1: 1 v / v$ water/ACN mixed-solvent system, a uniform orange polymer-electrolyte film without visible crystals was formed (Figure 1c), indicating
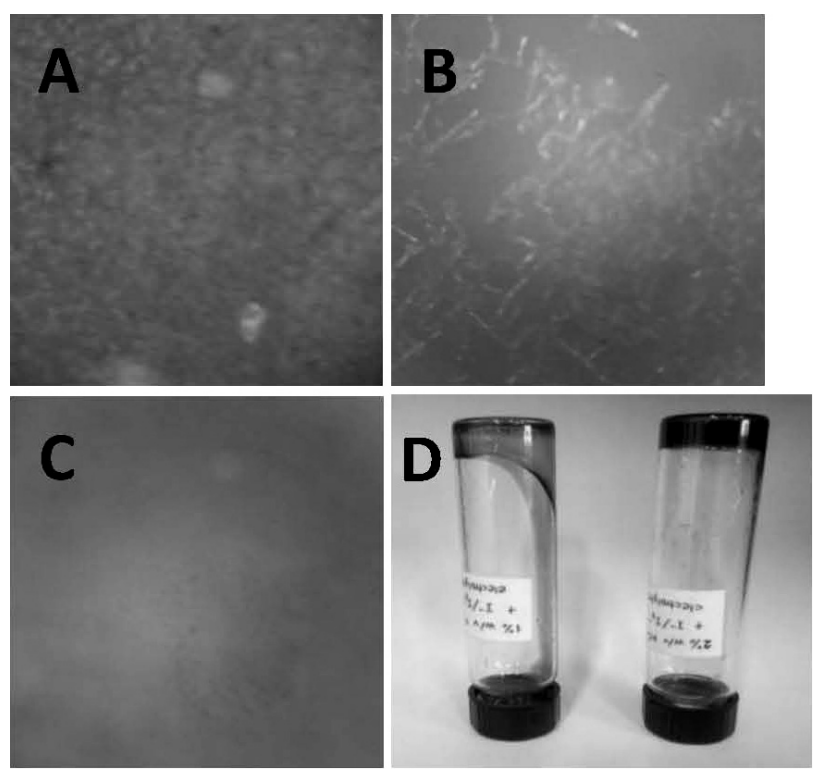

Figure 1: Optical images of $1 \% w / v \kappa$-carrageenan films mixed with $40 \% w / w$ TBAI (w.r.t. $\kappa$-carrageenan) in $4: 1$ mole ratio TBAI $/ I_{2}$ electrolyte in varying solvents a) in $100 \%$ water, b) in $3: 1$ $\mathrm{H}_{2} \mathrm{O} /$ acetonitrile, c) in 1:1 $\mathrm{H}_{2} \mathrm{O} /$ acetonitrile, d) polymer gel electrolytes containing $\kappa$-carrageenan and TBAI/LiI/ $\mathrm{I}_{2}$ electrolyte: left: $1 \% \mathrm{w} / v \kappa$-carrageenan in DMSO (liquid state), right: $2 \% \mathrm{w} / \mathrm{v}$ $\kappa$-carrageenan in DMSO (gel-state) good dissolution and incorporation of the $\mathrm{I}^{-} / \mathrm{I}_{3}{ }^{-}$redox couple in the polymer matrix. No films were cast for the $1: 3 \mathrm{v} / \mathrm{v}$ water/acetonitrile solvent systems and in $100 \%$ acetonitrile because of the relative insolubility of carrageenan in an acetonitrile-rich solvent.

The concentration of carrageenan in the polymer electrolyte containing $20 \% \mathrm{w} / \mathrm{w}$ TBAI (w.r.t. $\kappa$-carrageenan) in the $1: 1 \mathrm{H}_{2} \mathrm{O}$ /acetonitrile mixed solvent affects the property and the ionic conductivity of the electrolyte. A liquid polymer electrolyte is formed when the concentrations of carrageenan are in a range of $0.1-0.5 \%$ $w / v$. Increasing the carrageenan concentration to $\geq 1.0 \%$ $w / v$ gave a gel polymer electrolyte. Consequently, the ionic conductivity of the polymer electrolytes changes in response to its composite form. The ionic conductivity (Figure 2) of $\kappa$-carrageenan-electrolyte systems increases as the carrageenan concentration increases from 0.1 to $1.0 \% \mathrm{w} / \mathrm{v}$. The increase in the ionic conductivity at low $\kappa$-carrageenan concentrations is attributed to high free-ion concentrations due to their interaction with the functional group present in $\kappa$-carrageenan. ${ }^{16}$. The ionic conductivity decreases at carrageenan concentrations of $1.0-2.0 \% \mathrm{w} / \mathrm{v}$. The increase in the polymer concentration causes chain entanglements, impeding the movement of the ions, thus, decreasing its ionic conductivity. ${ }^{16}$

Different iodide salts were incorporated in $\kappa$-carrageenan to prepare the gel electrolytes. Films were formed and the IR spectra of the electrolyte films contained typical functional-group vibrations of $\kappa$-carrageenan. ${ }^{17}$ The bands at $1272 \mathrm{~cm}^{-1}$ were identified as an $\mathrm{O}=\mathrm{S}=\mathrm{O}$ symmetric vibration that would respond in the presence of a cation. A shift in the frequency was observed in the $\mathrm{O}=\mathrm{S}=\mathrm{O}$ symmetric vibration compared with the pure k-carrageenan reference (Table 1, entry 1). This shift is attributed to the electrostatic interaction between the negatively charged sulfate ions in the carrageenan chains and the positively charged cations from the iodide salt. ${ }^{4}$ The effect of the addition of iodide salts generally increased the electrical conductivity (Table 1, entry 2) of the films formed, as compared with

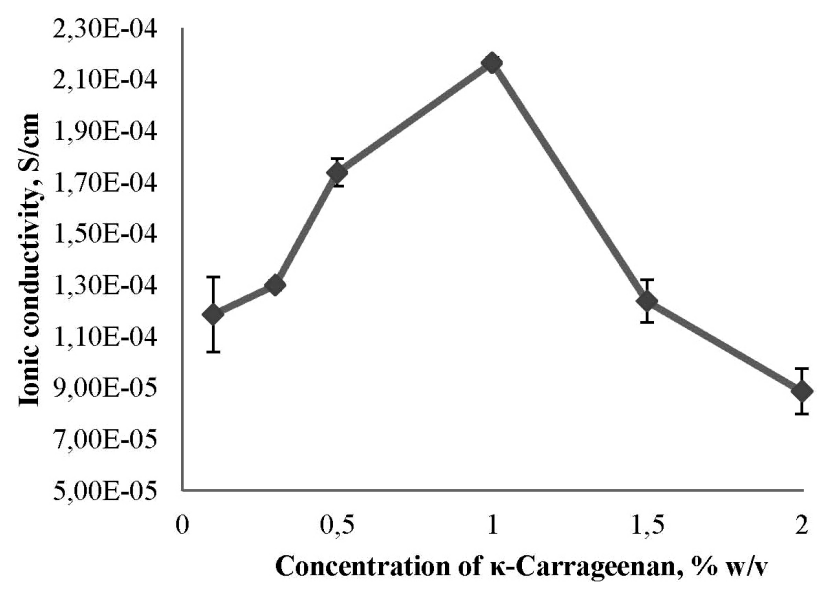

Figure 2: Effect of $\kappa$-carrageenan concentration on ionic conductivity of carrageenan/TBAI/I 2 systems 


\section{J. P. BANTANG, D. CAMACHO: GELLING POLYSACCHARIDE AS THE ELECTROLYTE MATRIX ...}

Table 1: FTIR and conductivity of the $\kappa$-carrageenan electrolytes containing different salts

\begin{tabular}{|c|c|c|c|c|c|c|}
\hline \multirow{2}{*}{\multicolumn{2}{|c|}{ Entry }} & \multirow{3}{*}{\begin{tabular}{|c|}
$\begin{array}{c}\text { Pure } \kappa \text { - carrageenan } \\
\text { (reference) }\end{array}$ \\
1272 \\
\end{tabular}} & \multirow{3}{*}{$\begin{array}{c}\text { Iodolyte AN50 } \\
\text { (control) }\end{array}$} & $\mathrm{KI} / \mathrm{I}_{2}$ & $\mathrm{TMSI} / \mathrm{I}_{2}$ & $\mathrm{TBAI} / \mathrm{I}_{2}$ \\
\hline & & & & \multicolumn{3}{|c|}{ in $\kappa$-carrageenan } \\
\hline 1 & FTIR $\mathrm{O}=\mathrm{S}=\mathrm{O}$ vibration $\left(\mathrm{cm}^{-1}\right)$ & & & 1261 & 1274 & 1263 \\
\hline 2 & $\begin{array}{l}\text { Electrical conductivity of } \\
\text { polymer-electrolyte films } \\
\left(\mathrm{S} \mathrm{cm}^{-1}\right)\end{array}$ & 0.127 & - & 0.281 & 0.189 & 0.326 \\
\hline 3 & $\begin{array}{l}\text { Ionic conductivity of } \\
\text { polymer-electrolyte gels } \\
\left(\mathrm{x} 10^{-4} \mathrm{~S} \mathrm{~cm}^{-1}\right)\end{array}$ & - & 1.66 & 2.52 & 3.05 & 2.17 \\
\hline
\end{tabular}

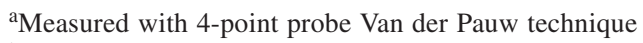

${ }^{b}$ Measured with electrochemical impedance spectroscopy (EIS)

the reference pure $\kappa$-carrageenan due to the addition and incorporation of the redox species. The ionic conductivities (Table 1, entry 3) of the gel electrolytes are generally higher than that of the acetonitrile-based liquid electrolyte, indicating a facile transport of the redox couple in the carrageenan matrix. Cyclic voltammetry of the gel electrolytes with and without $\kappa$-carrageenan (Figure 3) showed that the addition of the polymer does not impede the electrochemical behavior of the $\mathrm{I}^{-} / \mathrm{I}_{3}-$ redox couple in the mixed water/acetonitrile system. Two redox processes were observed, indicating the migration of $\mathrm{I}^{-} / \mathrm{I}_{3}{ }^{-}$in the $3 \mathrm{D}$ matrix of $\kappa$-carrageenan. ${ }^{18}$

Solar cells were fabricated using the conventional set-up composed of a $\mathrm{TiO}_{2} /$ ruthenium dye as the photoanode and a platinum counter electrode sandwiching the $\kappa$-carrageenan-gel electrolyte systems in water/ACN. I-V characteristics of the DSSCs (Table 2 and Figure 4a) containing the $\kappa$-carrageenan-gel electrolytes showed poor efficiency $(<0.10 \%)$ as compared to the liquid electrolyte $(2.33 \%)$, attributed to a much lower shortcircuit current, which can be associated with the presence of a significant amount of water in the electrolyte system. The presence of water causes dye detachment due to the weakening of the dye- $\mathrm{TiO}_{2}$ linkage, resulting in a limited amount of electrons injected from the excited state of the dye and consequently leading to the lowering of the short-circuit current. ${ }^{16}$ The obtained efficiencies of

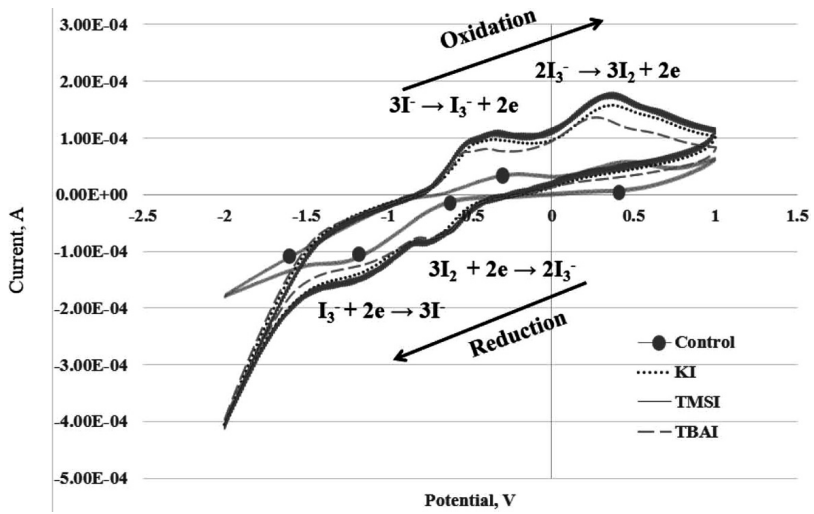

Figure 3: Electrochemical-behavior (cyclic voltametry) analysis of the $\kappa$-carrageenan-gel electrolytes containing different salts; control: $\mathrm{LiI} / \mathrm{I}_{2}$ in $1: 1 v / v$ water/ACN without carrageenan different $\kappa$-carrageenan-gel electrolytes with a mixture of acetonitrile and water suggest that imparting a large amount of water $(50 \%)$ in the electrolyte system for
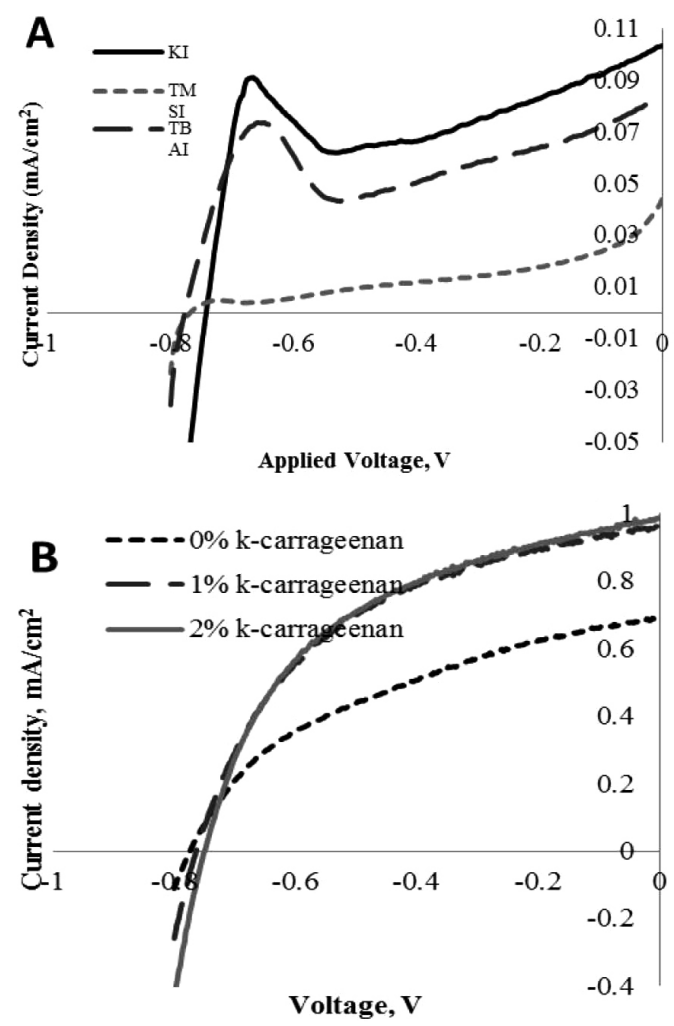

Figure 4: I-V curves of the DSSCs: a) containing different iodide salts (KI, TMSI and TBAI) in the water/ACN $\kappa$-carrageenan matrix and b) containing $\kappa$-carrageenan-based electrolytes in DMSO under a 100 $\mathrm{mW} / \mathrm{cm}^{2}$ illumination

Table 2: Characteristics of the fabricated DSSCs under a 100 $\mathrm{mW} / \mathrm{cm}^{2}$ illumination

\begin{tabular}{|c|c|c|c|c|}
\hline Electrolyte & $V_{\text {oc }}(\mathrm{V})$ & $\begin{array}{c}I_{\mathrm{sc}} \\
\left(\mathrm{mA} / \mathrm{cm}^{2}\right)\end{array}$ & $\mathrm{FF}$ & $\eta(\%)$ \\
\hline $\begin{array}{c}\text { Iodolyte } \\
\text { (control) }\end{array}$ & 0.695 & 6.444 & 0.521 & 2.333 \\
\hline $\mathrm{KI}: \mathrm{I}_{2}$ & 0.746 & 0.100 & 0.819 & 0.061 \\
\hline TMSI: $\mathrm{I}_{2}$ & 0.776 & 0.0414 & 0.152 & 0.005 \\
\hline TBAI: $\mathrm{I}_{2}$ & 0.778 & 0.0817 & 0.765 & 0.049 \\
\hline
\end{tabular}




\section{J. P. BANTANG, D. CAMACHO: GELLING POLYSACCHARIDE AS THE ELECTROLYTE MATRIX ...}

Table 3: I-V electrochemical properties of the carrageenan electrolyte in DMSO measured using two platinized FTO conducting glasses and I-V characteristics of DSSCs under a $100 \mathrm{~mW} / \mathrm{cm}^{2}$ illumination*

\begin{tabular}{|c|c|c|c|c|c|c|c|c|}
\hline & \multicolumn{4}{|c|}{ Electrochemical properties of electrolyte } & \multicolumn{4}{|c|}{$\mathrm{I}-\mathrm{V}$ characteristics of DSSC } \\
\hline $\begin{array}{c}\text { Electrolytes in } \\
\text { DMSO }\end{array}$ & $R_{\mathrm{b}}^{* *}(\Omega)$ & $\begin{array}{l}\mathrm{R}_{\mathrm{Pt}} \\
(\Omega)\end{array}$ & $\begin{array}{c}\text { Ionic con- } \\
\text { ductivity, } \\
\times 10^{-4}(\mathrm{~S} / \mathrm{cm})\end{array}$ & $\begin{array}{c}\text { Diffusivity of } \\
\mathrm{I}_{3}^{-}, \times 10^{-9} \\
\left(\mathrm{~cm}^{2} \mathrm{~s}^{-1}\right)\end{array}$ & $\begin{array}{c}\text { Short-circuit } \\
\text { current } \\
\left(\mathrm{mA} / \mathrm{cm}^{2}\right)\end{array}$ & \begin{tabular}{|l|} 
Open-circuit \\
voltage (V)
\end{tabular} & Fill factor & $\begin{array}{c}\text { Efficiency } \\
(\%)\end{array}$ \\
\hline $\begin{array}{c}\text { Control (without } \\
\kappa \text {-carrageenan) }\end{array}$ & 21.28 & 218.13 & 2.82 & 1.48 & 0.690 & 0.781 & 0.410 & 0.221 \\
\hline $\begin{array}{c}1 \% w / v \\
\kappa \text {-carrageenan }\end{array}$ & 25.33 & 296.41 & 2.37 & 1.41 & 0.960 & 0.763 & 0.483 & 0.354 \\
\hline $\begin{array}{c}2 \% w / v \\
\kappa \text {-carrageenan }\end{array}$ & 25.25 & 338.46 & 2.38 & 1.11 & 0.983 & 0.751 & 0.488 & 0.360 \\
\hline
\end{tabular}

*The electrolyte used was composed of tetrabutylammonium iodide $(0.5 \mathrm{M}), \mathrm{I}_{2},(0.05 \mathrm{M})$ and LiI $(0.1 \mathrm{M})$

${ }^{* *} R_{\mathrm{b}}$ corresponds to the solution resistance, which corresponds to the intercept at the real part of the EIS spectrum

DSSCs is still detrimental to the performance of a solarcell device.

\subsection{Carrageenan-electrolyte system in a non-aqueous solvent}

Carrageenan is not known to dissolve in purely nonaqueous solvents. However, in the course of our investigation of electrolyte systems, we observed that it dissolves in dimethylsulfoxide (DMSO). ${ }^{19,20}$ We investigated the solubility properties of $\kappa$-carrageenan in DMSO, dissolving different amounts of the biopolymer


Figure 5: a) EIS spectra of electrolytes measured using a symmetrical-cell set-up between two platinized FTO conducting glasses in a frequency range of $1 \mathrm{MHz}$ to $0.1 \mathrm{~Hz}, \mathrm{~b}$ ) linear sweep voltammogram of the electrolytes measured between two platinized FTO conducting glasses swept between $-1 \mathrm{~V}$ to $1 \mathrm{~V}$. Scan rate: $10 \mathrm{mV} / \mathrm{s}$ at $60{ }^{\circ} \mathrm{C}$. A liquid solution is formed with $1 \% \mathrm{w} / \mathrm{v}$ $\kappa$-carrageenan (a solubility of $0.01 \mathrm{~g} / \mathrm{mL}$ DMSO at room temperature and at $60{ }^{\circ} \mathrm{C}$ ). Increasing the $\kappa$-carrageenan concentration from 1.5 to $3.5 \% \mathrm{w} / \mathrm{v}$ allows the dissolution of the biopolymer in DMSO, forming a transparent solution at $60{ }^{\circ} \mathrm{C}$. However, upon cooling down at room temperature, it forms into a stable gel (Figure 1d). A further increase in the concentration of $\kappa$-carrageenan of $4-5 \% w / v$ leads to the formation of a stable gel even at $60{ }^{\circ} \mathrm{C}$. Other organic solvents such as ethanol, methanol, acetonitrile, tetrahydrofuran, dimethylformamide and methoxyethanol did not show good solubility. The advantages of using DMSO are its relatively low vapor pressure and relatively non-volatile nature, which are useful for maintaining its gel state. Moreover, this organic solvent shows a relatively low toxicity and is considered environmentally benign. ${ }^{6}$ The addition of electrolyte systems TBAI and $\mathrm{I}_{2}$ turned the $\kappa$-carrageenan DMSO solution into a dark-brown one indicating the incorporation of the electrolytes. The IR spectrum of the polymer-electrolyte system showed functional groups typical of $\kappa$-carrageenan. A shift in the $\mathrm{O}=\mathrm{S}=\mathrm{O}$ symmetric vibration from typical 1272 for pure $\kappa$-carrageenan to $1226 \mathrm{~cm}^{-1}$ for carrageenan gel electrolyte is attributed

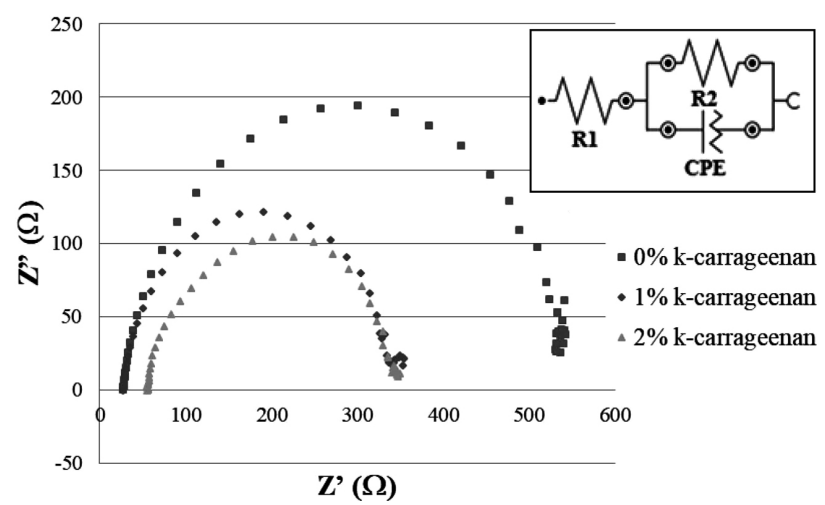

Figure 6: EIS spectrum of a DSSC containing $\kappa$-carrageenan-based electrolytes in DMSO; inset: equivalent circuit model $\left(R_{1}=\right.$ series resistance, $R_{2}=\mathrm{TiO}_{2} /$ dye/electrolyte interface resistance, $\mathrm{CPE}=$ constant phase element) 
to the interaction of the cation with the sulfate functional groups. ${ }^{5}$

The ionic conductivity and diffusivity of the tri-iodide ion (Table 3) in DMSO showed that the addition of $\kappa$-carrageenan decreases the ionic conductivity of the electrolyte system in comparison to the DMSO-based liquid-electrolyte system. EIS spectra (Figure 5a) of the electrolytes in DMSO show a broader semi-circle arc upon the addition of $\kappa$-carrageenan, which is associated with an increase in the charge-transfer resistance at the platinum/electrolyte interface $\left(R_{\mathrm{Pt}}\right)$. A higher $R_{\mathrm{Pt}}$ indicates a less efficient electro-activity at the Pt/electrolyte interface attributed to a slower ionic conductivity. ${ }^{21}$ The concentration of iodide ions is in excess in comparison with the amount of tri-iodide ions. Hence, the limiting current density of the gel electrolytes is associated with the diffusion coefficient of the tri-iodide ions. The limiting current densities of the electrolytes (Figure 5b) show negative and positive values due to the transport of charge carriers from one electrode to the other through the whole electrolyte system. ${ }^{8}$ A slow diffusion of the tri-iodide ions is consistent with the slow ionic conductivity of the carrageenan-electrolyte system. The slow tri-iodide ion diffusion in the $\kappa$-carrageenan electrolytes resulted in a higher recombination. ${ }^{22}$ These results were consistent with the decreasing trend in the open-circuit voltage of the electrolytes with $\kappa$-carrageenan. The photovoltaic performance of the $\kappa$-carrageenan-based dye-sensitized solar cells (Figure $\mathbf{4 b}$ and Table 3 ) showed that the addition of $\kappa$-carrageenan to the $\mathrm{I}^{-} / \mathrm{I}_{3}{ }^{-}$redox electrolyte system in dimethylsulfoxide decreases the open-circuit voltage and increases the short-circuit current of a solar cell. The improvement in the short-circuit current of the DSSCs with a $\kappa$-carrageenan/DMSO electrolyte system is attributed to the ability of the hydroxyl functional group and negatively charged sulfate ions of $\kappa$-carrageenan to allow dissociation of the ions in the polymer matrix through the electrostatic interaction with the cations. The enhancement in the short-circuit current of the $\kappa$-carrageenan/DMSO electrolytes is the major contribution to the improvement of the overall efficiency of the dye-sensitized solar cells. Good dissociation of ions in the polymer matrix increases the concentration of $\mathrm{I}^{-}$, its counterion, and $\mathrm{I}_{3}^{-}$leading to an increase in the short-circuit current. ${ }^{23}$

A typical liquid-electrolyte-based DSSC show an EIS spectrum consisting of three semi-circle arcs corresponding to the interfacial resistances occurring during the electrochemical reaction at the platinum/electrolyte interface, during the charge-transfer process at the $\mathrm{TiO}_{2} /$ dye/electrolyte interface and Warburg diffusion of $\mathrm{I}^{-} / \mathrm{I}_{3}{ }^{-}$in the electrolyte. A frequency-response-analyzer (FRA) impedance analysis of the $\kappa$-carrageenan/DMSO DSSC (Figure 6) showed a unique single semi-circle arc, associated with the charge-recombination process occurring at the $\mathrm{TiO}_{2} /$ dye/electrolyte interface (R2). The other parameters such as R1 and CPE corresponded to the series resistance and constant phase element, respectively. A decreasing trend in the semi-circle arc radius was observed when the $\kappa$-carrageenan concentration was increased. A quantitative approach of the recombination resistance was done by fitting the Nyquist plot with its corresponding equivalent circuit model. Chi-square values for the fitted equivalent circuit model range from $0.02-0.07$, indicating good value fitting. The chargerecombination resistances $(R 2)$ of the DSSCs without $\kappa$-carrageenan (control), with $1 \% \mathrm{w} / \nu \kappa$-carrageenan (liquid state) and $2 \% \mathrm{w} / \nu \kappa$-carrageenan (gel state), obtained from the plot are 515.19 $\Omega, 317.88 \Omega$ and $292.86 \Omega$, respectively. A higher $R 2$ value signifies lower charge recombination between the photoanode conduction-band electrons and $\mathrm{I}_{3}{ }^{-}$ions at the $\mathrm{TiO}_{2} /$ dye/electrolyte interface resulting in a higher $V_{\mathrm{oc}}{ }^{24}$ The higher charge recombination of the polymer electrolytes with $\kappa$-carrageenan, compared to the electrolyte without the polymer, is generally attributed to the slow ionic conductivity of the ions in the gel matrix of carrageenan (Table 3). Moreover, the $\kappa$-carrageenan electrolyte penetrates poorly into the $\mathrm{TiO}_{2}$ layer due to its polymeric nature contributing to the less efficient charge-transfer process. ${ }^{21}$ The results were consistent with the photovoltaic characteristics of the fabricated dye-sensitized solar cells.

\section{CONCLUSIONS}

A hydrophilic polysaccharide, $\kappa$-carrageenan, was successfully used as the polymer matrix for a gel-electrolyte system in a mixed solvent of water and acetonitrile for dye-sensitized solar cells. The solvent system improved the dissolution of the components and the electrolyte properties. Efficiencies of less than $0.1 \%$ of the fabricated DSSCs are attributed to the significant amount of water. A novel gel-polymer electrolyte consisting of $\kappa$-carrageenan electrolyte gel in DMSO was developed for DSSCs. Removal of the water from the polymer-electrolyte system improved the DSSC performance from 0.049 to $0.36 \%$, a seven-fold increase in the magnitude. The presence of $\kappa$-carrageenan in the DMSO-based gel-electrolyte system helps improve the solar-cell efficiency from 0.221 to $0.360 \%$.

\section{Acknowledgments}

The authors are grateful to Dr. Erwin Enriquez, Dr. Arnel Salvador and Dr. Armando Somintac for the use of the solar simulator and Ms. Anna San Esteban for guidance in solar measurements. This work was supported by research grants from DOST-PCIEERD of the Republic of the Philippines; DOST-SEI-ASTHRDP and DLSU-PhD Fellowship Grants to J. P. O Bantang; DLSU Research Faculty Grant, DLSU Science Foundation and DLSU-URCO to D. H. Camacho. 


\section{REFERENCES}

${ }^{1}$ J. R. MacCallum, C. A. Vincent, Polymer Electrolytes Reviews-1, Elsevier Applied Science, London, 1989

${ }^{2}$ K. N. Kumar, T. Sreekanth, M. J. Reddy, U. V. S. Rao, Study of transport and electrochemical cell characteristics of PVP: $\mathrm{NaClO}_{3}$ polymer electrolyte system, J. Power Sources, 101 (2001), 130-133 doi:10.1016/S0378-7753(01)00658-9

${ }^{3}$ T. M. W. J. Bandara, P. Ekanayake, M. A. K. L. Dissanayake, I. Albinsson, B. E. Mellander, A polymer electrolyte containing ionic liquid for possible applications in photoelectrochemical solar cells, J. Solid State Electrochem., 14 (2010), 1221-1226, doi:10.1007/ s10008-009-0951-X

${ }^{4}$ X. Guo, P. Yi, Y. Yang, J. Cui, S. Xiao, W. Wang, Effects of surfactants on agarose-based magnetic polymer electrolyte for dye-sensitized solar cells, Electrochim. Acta, 90 (2013), 524-529, doi:10.1016/j.electacta.2012.12.028

${ }^{5}$ R. Singh, A. R. Polu, B. Bhattacharya, H.-W. Rhee, C. Varlikli, P. K. Singh, Perspectives for solid biopolymer electrolytes in dye sensitized solar cell and battery application, Renew. Sustainable Energy Rev., 65 (2016), 1098-1117, doi:10.1016/j.rser.2016.06.026

${ }^{6}$ W. Wang, X. Guo, Y. Yang, Lithium iodide effect on the electrochemical behavior of agarose based polymer electrolyte for dye-sensitized solar cell, Electrochim. Acta, 56 (2011), 7347-7351, doi:10.1016/j.electacta.2011.06.032

${ }^{7}$ H.-L. Hsu, W.-T. Hsu, J. Leu, Effects of environmentally benign solvents in the agarose gel electrolytes on dye-sensitized solar cells, Electrochim. Acta, 56 (2011), 5904-5909, doi:10.1016/j.electacta. 2011.04.117

${ }^{8}$ P. Li, Y. Zhang, W. Fa, Y. Zhang, B. Huang, Synthesis of a grafted cellulose gel electrolyte in an ionic liquid ([Bmim]I) for dye-sensitized solar cells, Carbohydr. Polym., 86 (2011), 1216-1220, doi:10.1016/j.carbpol.2011.06.017

${ }^{9}$ X. Huang, Y. Liu, J. Deng, B. Yi, X. Yu, P. Shen, S. Tan, A novel polymer gel electrolyte based on cyanoethylated cellulose for dye-sensitized solar cells, Electrochim. Acta, 80 (2012), 219-226, doi:10.1016/j.electacta.2012.07.014

${ }^{10}$ M. Kaneko, T. Hoshi, Y, Kaburagi, H. Ueno, Solid type dye-sensitized solar cell using polysaccharide containing the redox electrolyte solution, J. Electroanal. Chem., 572 (2004), 21-27, doi:10.1016/ j.jelechem.2004.05.021

${ }^{11} \mathrm{H}$. Ueno, M. Kaneko, Investigation of a nanostructured polysaccharide solid medium for electrochemistry, J. Electroanal. Chem., 568 (2004), 87-92, doi:10.1016/j.jelechem.2003.12.044

${ }^{12}$ N. N. Mobarak, N. Ramli, A. Ahmad, M. Y. A. Rahman, Chemical interaction and conductivity of carboxymethyl $\kappa$-carrageenan based green polymer electrolyte, Solid State Ionics, 224 (2012), 51-57, doi:10.1016/j.ssi.2012.07.010
${ }^{13}$ F. Bella, N. N. Mobarak, F. N. Jumaah, A. Ahmad, From seaweeds to biopolymeric electrolytes for third generation solar cells: An intriguing approach, Electrochim. Acta, 151 (2015), 306-311, doi:10.1016/j.electacta.2014.11.058

${ }^{14}$ C. Law, S. C. Pathirana, X. Li, A. Y. Anderson, P. R. F. Barnes, A. Listorti, T. H. Ghaddar, B. C. O'Regan, Water-Based Electrolytes for Dye-Sensitized Solar Cells, Adv. Mater., 22 (2010), 4505-4509, doi:10.1002/adma.201001703

${ }^{15}$ D. H. Camacho, S. J. M. Tambio, M. I. A. Oliveros, CarrageenanIonic Liquid Composite: Development of Polysaccharide-Based Solid Electrolyte System, The Manila J. of Science, 6 (2011), 8-15

${ }^{16}$ H.-L. Lu, Y.-H. Lee, S.-T. Huang, C. Su, T. C.-K. Yang, Influences of water in bis-benzimidazole-derivative electrolyte additives to the degradation of the dye-sensitized solar cells, Sol. Energy Mater. Sol. Cells, 95 (2011), 158-162, doi:10.1016/j.solmat.2010.02.018

${ }^{17}$ C. Tranquilan-Aranilla, N. Nagasawa, A. Bayquen, A. Dela Rosa, Synthesis and characterization of carboxymethyl derivatives of kappa-carrageenan, Carbohydr. Polym., 87 (2012), 1810-1816, doi:10.1016/j.carbpol.2011.10.009

${ }^{18}$ S. Yuan, Q. Tang, B. He, P. Yang, Efficient quasi-solid-state dye-sensitized solar cells employing polyaniline and polypyrrole incorporated microporous conducting gel electrolytes, J. Power Sources, 254 (2014), 98-105, doi:10.1016/j.jpowsour.2013.12.112

${ }^{19}$ S. Chan, J. P. Bantang, D. Camacho, Influence of Nanomaterial Fillers in Biopolymer Electrolyte System for Squaraine-Based Dye-Sensitized Solar Cells, Int. J. Electrochem. Sci., 10 (2015), 7696-7706

${ }^{20}$ J. P. Bantang, D. Camacho, A Novel Biopolymer Gel Electrolyte System for DSSC Applications, Proceedings of the DLSU Research Congress, 3, 2015

${ }^{21}$ S. Venkatesan, N. Obadja, T.-W. Chang, L.-T. Chen, Y.-L. Lee, Performance improvement of gel- and solid-state dye-sensitized solar cells by utilization of the blending effect of poly (vinylidene fluoride-cohexafluropropylene) and poly (acrylonitrile-co-vinyl acetate) co-polymers, J. Power Sources, 268 (2014), 77-81, doi:10.1016/j.jpowsour.2014.06.016

${ }^{22}$ H.-L. Hsu, C.-F. Tien, Y.-T. Yang, J. Leu, Dye-sensitized solar cells based on agarose gel electrolytes using allylimidazolium iodides and environmentally benign solvents, Electrochim. Acta, 91 (2013), 208-213, doi:10.1016/j.electacta.2012.12.133

${ }^{23}$ K. Hara, T. Horiguchi, T. Kinoshita, K. Sayama, H. Arakawa, Influence of electrolytes on the photovoltaic performance of organic dye-sensitizednanocrystalline $\mathrm{TiO} 2$ solar cells, Sol. Energy Mater. Sol. Cells, 70 (2001), 151-161, doi:10.1016/S0927-0248(01)00019-8

${ }^{24}$ Y. Yang, J. Cui, P. Yi, X. Zheng, X. Guo, W. Wang, Effects of nanoparticle additives on the properties of agarose polymer electrolytes, J. Power Sources, 248 (2014), 988-993, doi:10.1016/ j.jpowsour.2013.10.016 